\title{
Design and Build a Modern Parking Application Based on Android
}

\author{
Ilham Ilyas \\ Software Engineering Technology, \\ Agriculture Polytechnic of \\ Samarinda, Samarinda, 75242, \\ Indonesia \\ ilhamilyas100@gmail.com
}

\author{
Eko Junirianto (i)* \\ Software Engineering Technology, \\ Agriculture Polytechnic of \\ Samarinda, Samarinda, 75242, \\ Indonesia \\ eko@politanisamarinda.ac.id \\ *Corresponding author
}

\author{
Annafi Franz \\ Software Engineering Technology, \\ Agriculture Polytechnic of \\ Samarinda, Samarinda, 75242, \\ Indonesia \\ annafifranz@gmail.com
}

Received: 2020-10-18; Revised: 2021-08-14; Accepted: 2021-10-08; Published: 2021-12-01

\begin{abstract}
Parking is a non-moving condition of a vehicle that is not temporary. Problem associated parking di Samarinda is disparity between revenue targets with the realization of revenue from parking fees. The performance of roadside parking management is not optimal yet, where there are still many illegal parking officers. While their official parking attendants tend to be dishonest and do not hand over parking fee tickets to motorists , this study offers a solution that might solve the above problems by creating an android -based parking application made for parking attendants, this application is used by parking attendants to recorded all parked vehicles and stored directly on the web service. The Apps is made using Android Studio and Postman to test the API provided. The results of this study are expected to reduce the impact of disparities between revenue targets and revenue realization from parking fees.
\end{abstract}

Keywords - Parking, Parking Officers, Android Application, Parking Application

\section{INTRODUCTION}

Samarinda City is one of the fastest growing areas with a population that continues to increase every year. In line with increasing population growth, the number of private vehicles owned by Samarinda residents has also increased as well, resulting in a high flow of vehicles on the highway and increasing the need for parking areas. This condition certainly requires the local government, as a public servant, to be able to provide facilities and infrastructure in regulating the flow of vehicles as well as providing adequate parking services for Samarinda residents. Parking areas cannot be provided just anywhere, but indepth studies are needed so that the impact of the parking area does not interfere with public order. In addition, the parking area also needs to be provided with parking officers who can direct the vehicle so that it is neatly organized and does not interfere with the flow of public road traffic for safety and comfort. The existence of parking attendants at the same time can maintain the safety of vehicles parked in that place from criminal acts.

One of the problems related to parking in Samarinda is the disparity between the revenue target and the actual revenue from parking fees. The performance of roadside parking management is not optimal yet, where there are still many illegal parking officers.

In this digital era, there are many technologies that really help human work, one of which is Android. Android provides an open platform for developers to create their own applications for use by a variety of mobile devices. Android is an operating system that is widely used today. This is supported by major vendors, such as Samsung, HTC, LG, who use this operating system. So that makes Andoid popular faster than other smartphone operating systems.

\section{LITERATURE REVIEW}

\section{A. Study of Literature}

Some of the literature as a guide and reference in this paper:

1. Research conducted by Guistia, et al (2015), in a study entitled "Making Geographical Information System Applications for the Diponegoro University Campus Based on Android". This study uses spatial and non-spatial data from Diponegoro University, both in the form of location coordinates, photos, campus maps and information on various buildings as well as lecturer data and information on each department and faculty. With the popularity of Android smartphones, it has become a campus information system platform for Diponegoro University. This application was developed using the Android SDK Framework, java programming language and PHP, MySQL as a database, and Google Maps.

2. Research conducted by Susanto, et al (2017), in a study entitled "prototype e-parking to support the increase in regional revenue (PAD) of the city of Pekalongan" discusses solutions to overcome leaks in the management of parking tax funds by implementing electronic parking or E-Parking, so that the monitoring process of all matters relating to parking can be done well, and have an impact on increasing local revenue from the parking tax sector.

3. Research conducted by Ary Budi Warsito, et al (2017), in a study entitled "Application of an 
Android-Based Vehicle Parking Monitoring System at Raharja College" discusses the design of an Android-based monitoring system that will count the parked vehicles. With the application of the Androidbased Monitoring system, it is hoped that it can overcome existing problems so that it makes it easier for officers in terms of monitoring the state of the parking area at Raharja College and also getting information about the number of parking slots remaining in real time and automatically and easing officers in registering outgoing vehicles come in.

4. Research conducted by Mawaddah (2017), in a study entitled "QR Code-based parking scan mobile application in a Co-Working Space Vacuum", a computerized parking system using a mobile application as a scanner and QR Code technology. The use of QR Code as a parking medium is expected to increase security in the supervision and validation of the parking system. The system is built with the Java NetBeans programming language and MySQL as the database and using our smartphone as a scanner with the Kinoni software application which can be downloaded on the Play store and for a PC or laptop we can download Kinoni for PC for free. The methodology used in system development uses the Waterfall method, a method that is often used in system development. From the results of trials conducted by researchers, this application can run well, so the Vacuum Co-working space can use this application to help manage the estimates there.

5. Research conducted by Ichwana \& Syahputra (2017), In a study entitled "Parking Payment System Using Android-Based Near Field Communication And Internet Of Things Technology," the study describes the design of a parking payment system using NFC (Near Field Communication) and GPS (Global Position System) to create smarter parking payment methods. The contribution given from the research results is to apply the concept of pervasive computing and the Internet of Things (IoT) in the construction of the parking system, so that the parking payment process becomes more effective. WIFI mounted parking location and unique SSID name. The system will perform sensing on users who enter the parking location using the IMEI. Payment for parking using an application on a smartphone with NFC Enable by bringing it closer to the NFC reader on the system.

\section{B. Android}

Android is a Linux-based operating system designed for touch screen mobile devices such as smartphones and tablet computers. Android was originally developed by Android, Inc., with financial support from Google, which then bought it in 2005. This operating system was officially released in 2007, together with the founding of the Open Handset Alliance, a consortium of hardware, software, and hardware companies and telecommunications which aim to advance open standards of mobile devices. The first Android phones went on sale in October 2008.
The Android user interface is generally direct manipulation, using touch gestures that are similar to real actions, such as swiping, tapping, and pinching to manipulate objects on the screen, and a virtual keyboard to write text. Apart from touch screen devices, Google has also developed Android TV for televisions, Android Auto for cars, and Android Wear for watches. Each of them has a different user interface. The Android variant is also used on laptops. Console games, digital cameras, and other electronic equipment(Yudhanto, 2018).

Android devices have several hardware features in them. This is what developers can use in building applications. Among others are:

a. Touchscreen.

Android devices have a touch screen feature that provides several possibilities for users to interact with applications using their fingers.

b. GPS.

The Android operating system supports GPS which allows developers to access the user's location

c. Accelerometer.

Device used to measure acceleration.

d. SD Card.

Android has a feature that allows users or applications to access (save or open) files on the SD Card.

Android has many software features that can be used by developers in developing applications, namely:

a. Internet.

Internet access capabilities on Android provide many advantages. A variety of real-time information can be obtained easily on the internet.

b. Audio and Video Support.

The Android operating system allows developers to easily include audio and video in their applications.

c. Contact.

Android allows access to contacts stored on the device.

d. Google APls.

The Android operating system allows unlimited phone calls, organizing contacts or installing applications. Developers can also integrate the map (map) into an application by using the Maps API which contains Map Widgets.

\section{Software DevelOpent Kit}

You must be wondering. How then various applications on the Play Store can be available and can be downloaded by every android user. Yes, there is a software or software that you can use to build various android applications. The Software Development Kit or SDK is a kit that functions to develop various Android-based applications by developers. In the SDK, there are various tools aimed at the application development process such as the debugger process, emulator, software libraries, documentation, tutorials and code samples. The software's specialty is Android Studio(Firly, 2018). 


\section{Java Devlopment Kit}

JDK is a development environment for building applications and components using the Java programming language. JDK includes useful tools for developing, testing, and monitoring programs written in the Java programming language and running on the Java platform. The Online Java Platform, Standard Edition (Java SE) Documentation contains API specifications, feature descriptions, developer guides, reference pages for JDK tools and utilities, demos, and links to related information. Java SE documentation is also available in a downloadable bundle that we can install(Admin, 2019). can be seen in picture 1 .

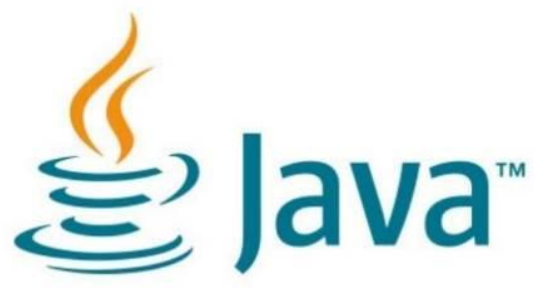

Picture 1. Java $\log 0$

\section{E. Parking Management}

Parking management is regulated in a regional regulation on parking so that it has legal force and there are prohibited signs, directions and information. To increase public compliance with the policies implemented in parking control, it is necessary to take decisive steps in taking action against parking policy violators. According to the Decree of the Director General of Land Transportation Number 272 / HK.105 / DRJD / 96, Parking is the immovable state of a vehicle that is not temporary. While stopping is the state of not moving a vehicle for a while with the driver not leaving the vehicle. Parking rates are a very useful tool for controlling the number of parked vehicles. The basis for determining the charges for parking services on the side of public roads is Law No. 28 of 2009 on Regional Taxes and Regional Levies, which also regulates the imposition of taxes on the operation of parking spaces outside the road body, whether provided in relation to the main business or those provided as a business, including the provision of a motorized vehicle custody(Wulandari, 2015).

\section{F. System Usability Scale (SUS)}

System usability scale is scale that used to assessment of usability system. This method has been used by so many people to testing software, because it is easy to use and the result could be consideration. Another reason using this method is easy to understanding and easy to use, so that this method is popular to usability testing(Jiwa Permana, 2019).

This method has 10 questions and 5 answer options. The maximal score is 100 and minimal is 0 . The 10 questions can be seen in table 1 and the 5 answer questions can be seen in table 2 .
Table 1. List Question of SUS

\begin{tabular}{|c|c|}
\hline No. & Question \\
\hline 1 & I think that I would like to use this system frequently. \\
\hline 2 & I found the system unnecessarily complex. \\
\hline 3 & I thought the system was easy to use. \\
\hline 4 & $\begin{array}{l}\text { I think that I would need the support of a technical person to be } \\
\text { able to use this system. }\end{array}$ \\
\hline 5 & $\begin{array}{l}\text { I found the various functions in this system were well } \\
\text { integrated. }\end{array}$ \\
\hline 6 & I thought there was too much inconsistency in this system. \\
\hline 7 & $\begin{array}{l}\text { I would imagine that most people would learn to use this system } \\
\text { very quickly. }\end{array}$ \\
\hline 8 & I found the system very cumbersome to use. \\
\hline 9 & I felt very confident using the system. \\
\hline 10 & $\begin{array}{l}\text { I needed to learn a lot of things before I could get going with } \\
\text { this system. }\end{array}$ \\
\hline
\end{tabular}

Table 2. List Answer option of SUS

\begin{tabular}{|c|l|c|}
\hline No. & \multicolumn{1}{|c|}{ Option } & Score \\
\hline 1 & Strongly Disagree & 1 \\
\hline 2 & Disagree & 2 \\
\hline 3 & Half and half & 3 \\
\hline 4 & Agree & 4 \\
\hline 5 & Strongly Agree & 5 \\
\hline
\end{tabular}

After collecting data from respondents, data will be measure to find out the average score from all respondents. The average score will be conclude by SUS score to find out in which grade. SUS score can be seen in picture 2 .

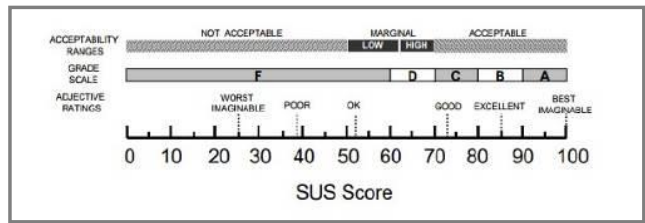

Picture 2. SUS Score

\section{RESEARCH METHODS}

\section{A. Research Procedure}

Research procedure can be seen in picture 3. This research procedure is shown as flow chart diagram. 


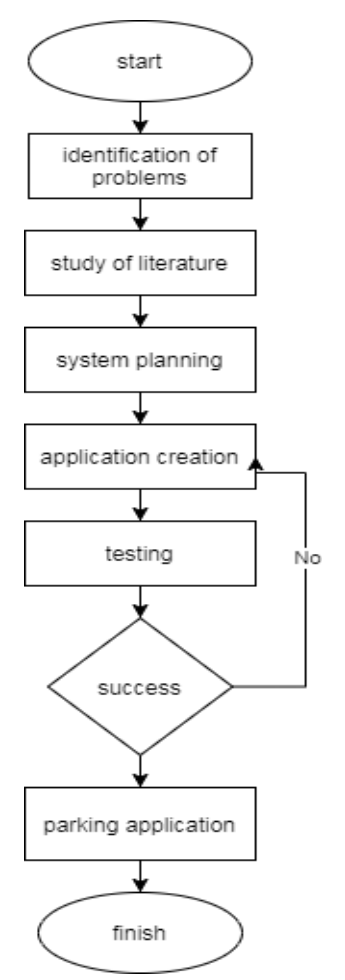

Picture 3. Research Procedure

In this research, the stages of making the Modern Parking application use the Waterfall method. The Waterfall method or what is often referred to as the waterfall method is a development method that is carried out sequentially and continuously in building a system. This method can be seen in picture 4 .

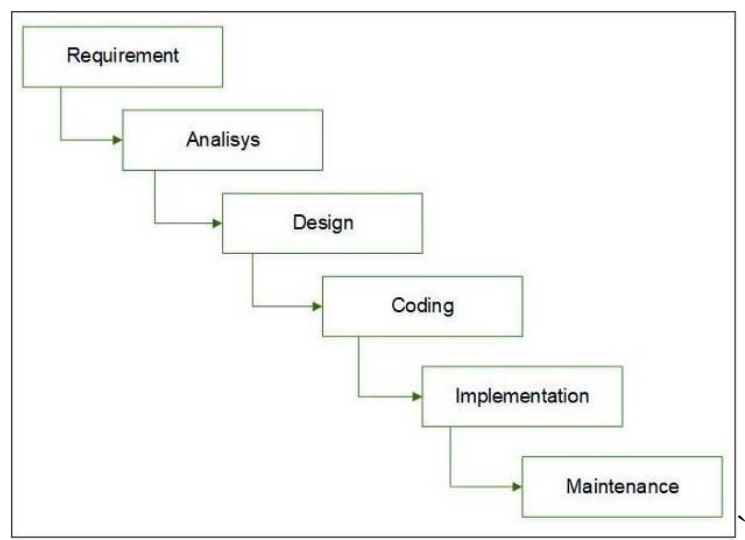

Picture 4. Waterfall Method

\section{B. System Design}

In picture 5 we can see the interface design consisting of the home menu, transactions and profiles.

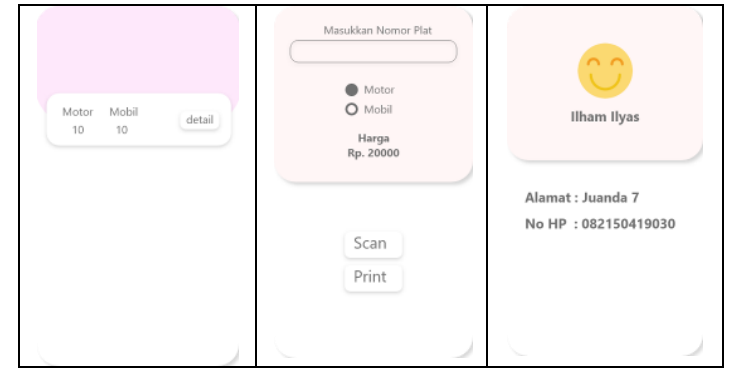

Picture 5. User Interface Design

C. Analysis System

1. Use Case Diagram

Use Case Diagram describes what the system will do and who interacts with the system. The following is the design of the Use Case Diagram from the Modern Parking application can be seen in picture 6 .

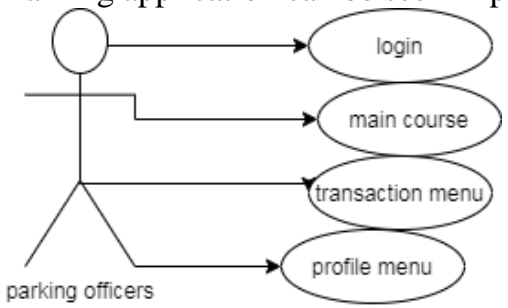

Picture 6. Use Case Diagram

2. Diagram Activity of Login

Picture 7 is an explanation of the login flow carried out by the parking attendant in the form of an activity diagram. The parking attendant will start logging in by entering the registered account, then the application will validate the account, if the wrong account fails to log in, if the account is correct, the parking attendant will successfully log in and be able to access the menus in the Modern Parking application.

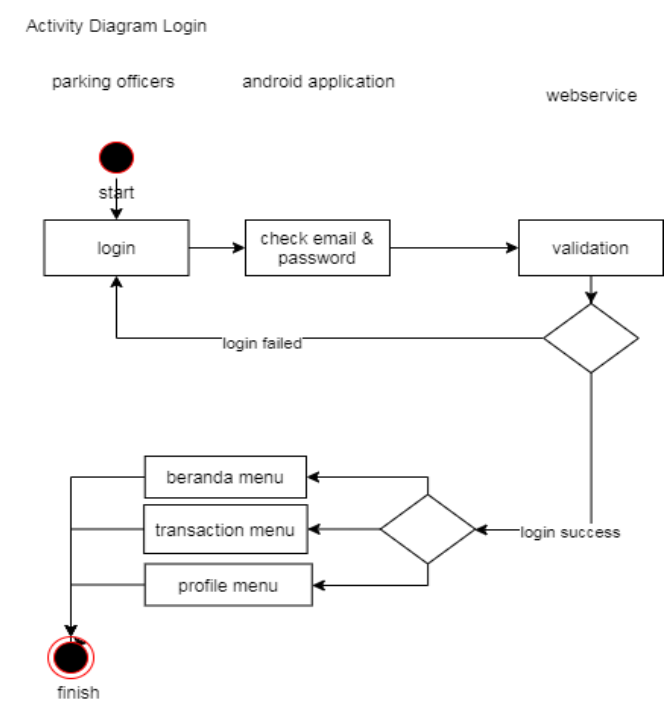

Picture 7. Login Activity Diagram 
3. Activity Diagram Transactions

Picture 8 describes the flow of the transaction process between parking attendants and visitors which is described in the form of an activity diagram.

$$
\text { Activity diagram Transakasi }
$$

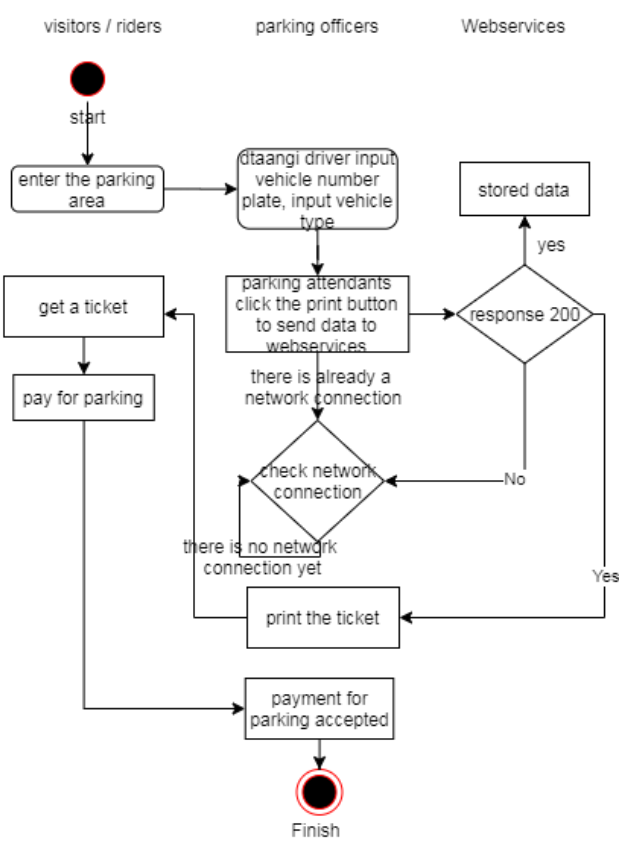

Picture 8. Activity Diagram Trasanction

\section{Diagram Activity of Detail Transactions}

Picture 9 explains the flow of parking attendants seeing transaction details on the Modern Parking application. This explanation uses an activity diagram.

Activity diagram detail transaksi

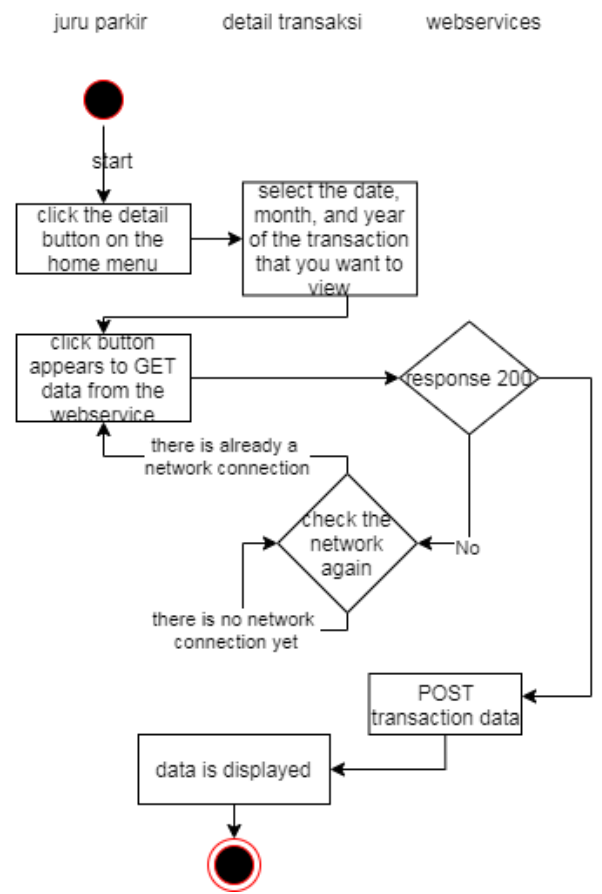

Picture 9. Activity Diagram Detail Transaction

\section{RESULT AND DISCUSSION}

A. Implementation Interface

1. Splashscreen page

Picture 10 is the splashscreen that appears the first time the application is opened, this section usually displays the application logo, application name, how to use the application.

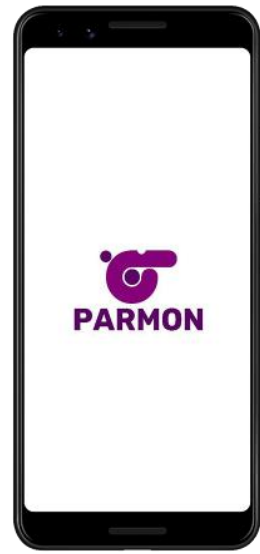

Picture 10. Splashscreen Page Interface

2. Login Page

Picture 11 used by parking attendants by entering an account based on the account provided by the Modern Parking web admin so that parking attendants can access all Modern Parking application menus.

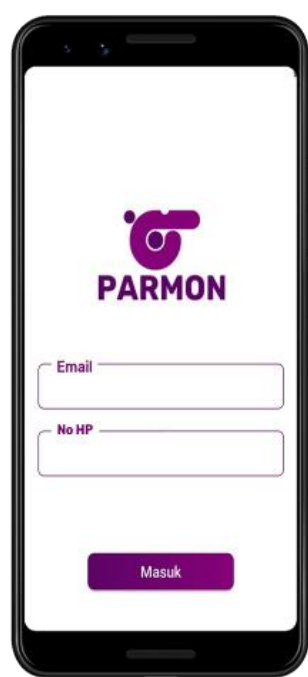

Picture 11. Login Page Interface

\section{Home Page}

Picture 12 shows, There are several sections, the upper part is the section that contains general information about modern parking which is presented in the form of a viewpager. The middle part in the form of a Card view is the part that provides information about the number of parked vehicles. 


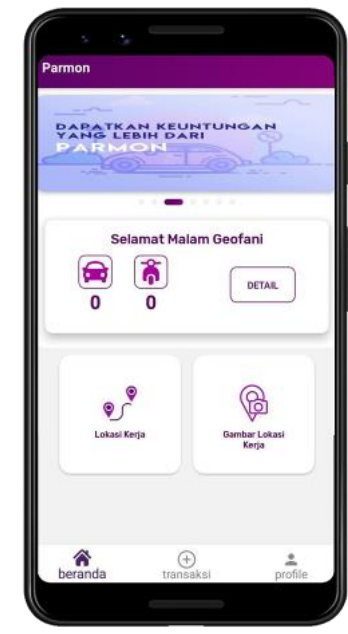

Picture 12. Home Page Interface

\section{Detail Transaction Page}

Picture 13 has 2 parts, namely section (a) which displays transactions for the parking attendant's working day, and section (b) displays all transactions that have been carried out by the parking attendant. In this section, parking attendants can choose the data they want to display based on the date, month and year.

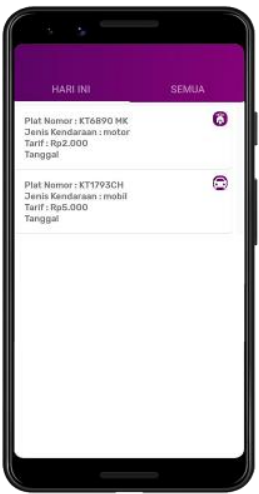

(a)

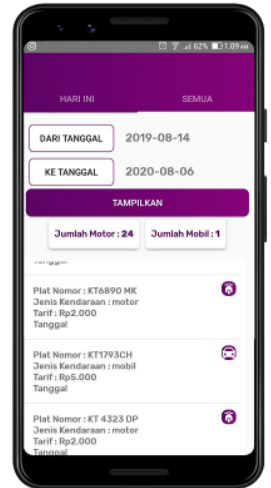

(b)
Picture 13. Detail Transaction Page Interface

\section{Transaction Page}

Picture 14 shows, the display of the transaction menu where the parking attendant can fill the vehicle plate using 2 ways, the first way is to use the text recognition feature by pressing the scan button, the second way is to fill in the text input manually, after all data is filled in Bluetooth thermal printer, after that if the text under the print button will change from "status" to "Connected with device" means the printer is connected to the application. Then click the print button to print parking tickets, the results can be seen in 15 .

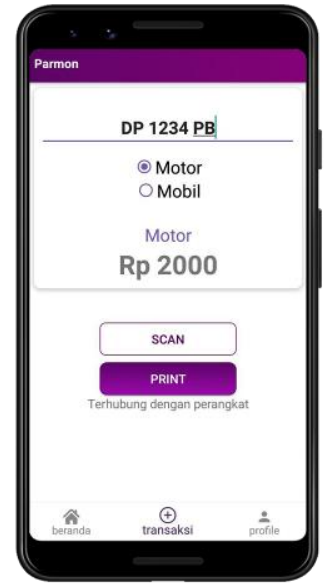

Picture 14. Transaction Page Interface

6. Printer Thermal Bluetooth

Printer thermal bluetooth can be seen in picture 15 .

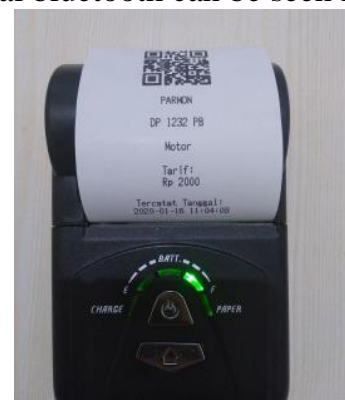

Picture 15. Printer Thermal Bluetooth

\section{Profile Page}

Picture 16 is a menu that contains the parking attendant's personal data, and is available button logout.
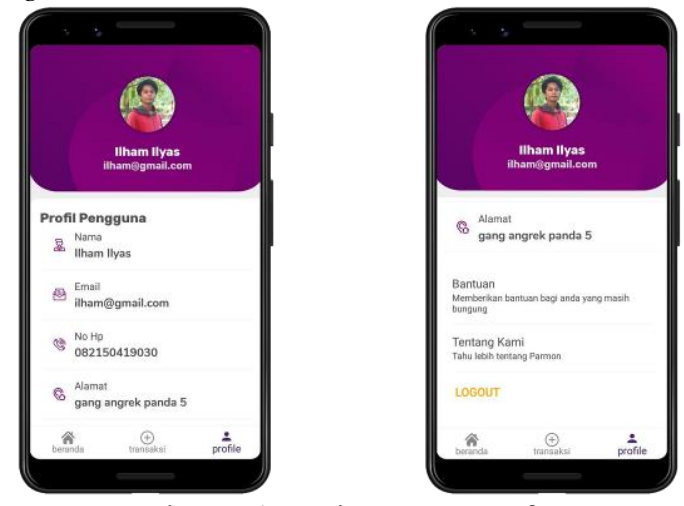

Picture 16. Print Page Interface

\section{B. Testing}

In running a modern parking application, the authors test as shown in table 3 . 
Table 3. Application Test Scheme

\begin{tabular}{|c|c|c|c|}
\hline$\#$ & Validation & Success & Fail \\
\hline 1 & $\begin{array}{l}\text { Has the application succeeded in sending } \\
\text { transaction data (vehicle id and vehicle } \\
\text { number plate) based on the logged in } \\
\text { parking attendant? }\end{array}$ & $\checkmark$ & \\
\hline 2 & $\begin{array}{l}\text { Has the data on the number of motorbikes } \\
\text { and cars been displayed based on the } \\
\text { working day of each parking attendant? }\end{array}$ & $\checkmark$ & \\
\hline 3 & $\begin{array}{l}\text { Can the application display today's } \\
\text { transaction history data based on each } \\
\text { logged in parking attendant? }\end{array}$ & $\checkmark$ & \\
\hline 4 & $\begin{array}{l}\text { Can the application display all transaction } \\
\text { history data based on the logged in parking } \\
\text { attendant? }\end{array}$ & $\checkmark$ & \\
\hline 5 & $\begin{array}{l}\text { Can the application display profile data } \\
\text { based on the logged in parking attendant? }\end{array}$ & $\checkmark$ & \\
\hline
\end{tabular}

As for the test results contained in table 3 , all the functions contained in the modern parking application have been running well, starting from sending transaction data, displaying data on the number of motorbikes and the number of cars based on the working day of each parking attendant, the application displays transaction history data today based on the logged in parking attendant, the application displays all transaction history data based on the logged in parking attendant, and finally the application can display parking attendant data based on the logged parking attendant.

\section{Modern Parking application UI / UX Design Testing}

UI / UX design testing in modern parking applications was carried out using the SUS (System Usability Scale) questionnaire which can be seen in table 4.

Table 4. SUS Test Result

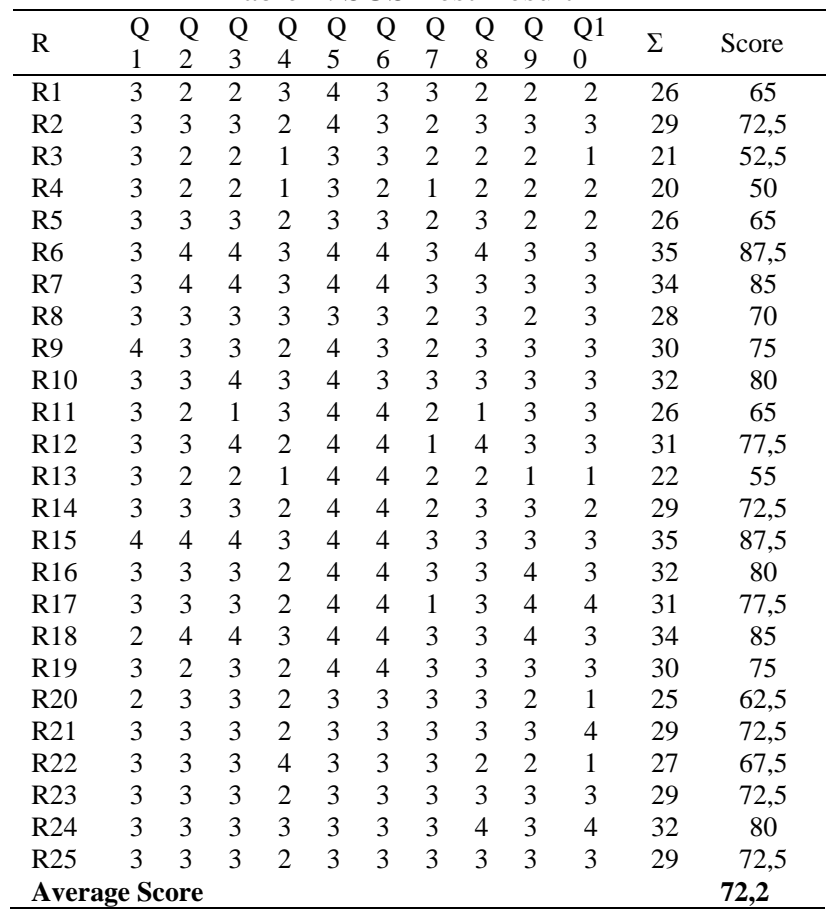

After calculating the results of the collected respondent data where to calculate the SUS value, for each total value of each question in times 2.5 and all the results are added up to calculate the average value of the SUS score so that you get a value of 72.2. This proves that the test of modern parking applications is acceptable because the value generated from the respondents' results is above average and gets a good grade Scale $\mathrm{C}$ rating.

\section{CONCLUSION}

The design and manufacture of the Modern Parking application that has been carried out can be concluded that the application can run properly, and has been tested by several respondents using the SUS method by obtaining a score of 72.2. The score has met the requirements in the basis for assessing the SUS score and getting a good rating.

\section{REFERENCES}

Admin. (2019). Java ${ }^{\mathrm{TM}}$ Platform Standard Edition 11 Development Kit JDK ${ }^{\mathrm{TM}} 11$. Retrieved from https://www.oracle.com/technetwork/java/javase/do wnloads/jdk11-readme-5097204.html

Firly, N. (2018). Create Your Own Android Application. Retrieved from https://books.google.co.id/books?id=4LBfDwAAQ BAJ\&hl=id\&source=gbs_navlinks_s

Guistia Puspa Geoda, Suprayogi, A., \& Hani'ah. (2015). Pembuatan Aplikasi Sistem Informasi Geografis Kampus Universitas Diponegoro Berbasis Android. Teknik Geodesi Fakultas Teknik, Unversitas Diponegoro, 4(April), 267-276.

Ichwana, D., \& Syahputra, W. (2017). Sistem Pembayaran Parkir Menggunakan NEAR FIELD COMMUNICATION Berbasis ANDROID dan Teknologi INTERNET OF THINGS. Jurnal Nasional Teknologi Dan Sistem Informasi, 3(1), 153-164.

https://doi.org/10.25077/teknosi.v3i1.2017.153-164

Jiwa Permana, A. A. (2019). Usability Testing Pada Website E-Commerce Menggunakan Metode System Usability Scale (SUS) (Studi Kasus : UMKMBULELENG.Com). JST (Jurnal Sains Dan Teknologi), 8(2), 149. https://doi.org/10.23887/jstundiksha.v8i2.22858

Mawaddah, N. (2017). APLIKASI MOBILE SCAN PARKIR BERBASIS QR CODE Nurul. (70), 138143.

Susanto, E. B., Wahyu Binabar, S., \& Maulana, M. R. (2017). Prototipe E-Parkir Untuk Mendukung Peningkatan Pendapatan Asli Daerah (Pad) Kota Pekalongan. 13.

Wulandari, S. (2015). Pengelolaan Parkir Tepi Jalan Oleh UPTD Pengelola Parkir Pada Dinas Perhubungan Di Kota Samarinda. 3(1), 35-46.

Yudhanto, Y. \& W. A. (2018). Mudah Membuat dan Berbisnis Aplikasi Android dengan Android Studio. Kompas Gramedia, pp. 17-36. 